\title{
Factors Influencing Cassava Farmers' Climate Change Risk Perception in Anambra State, Nigeria
}

\author{
Christopher Akujuobi Emenyonu*, Chiedozie Christopher Eze, Onyekachukwu Umeadi Ejike \\ Department of Agricultural Economics, Federal University of Technology, Owerri, Nigeria \\ Email: *cemenyonu@yahoo.com, *chrisemenyonu@gmail.com
}

How to cite this paper: Emenyonu, C. A., Eze, C. C., \& Ejike, O. U. (2020). Factors Influencing Cassava Farmers' Climate Change Risk Perception in Anambra State, Nigeria. American Journal of Climate Change, 9, 217-227.

https://doi.org/10.4236/ajcc.2020.93014

Received: February 5, 2020

Accepted: September 1, 2020

Published: September 4, 2020

Copyright $\odot 2020$ by author(s) and Scientific Research Publishing Inc. This work is licensed under the Creative Commons Attribution International License (CC BY 4.0).

http://creativecommons.org/licenses/by/4.0/

\begin{abstract}
This study analyzed the determinants of climate change risk perception among cassava farmers in Anambra state, Nigeria. The specific objectives were to describe the socio-economic characteristics of cassava farmers in the area and to examine the farmers' climate change risk perception through examining their perception of the various sources of climate change risk. Multi-stage sampling technique was used to select one hundred and sixty (160) respondents who were selected from 40 communities and 8 Local Government Areas from across the four Agricultural Zones of the state. Data were obtained through the administration of structured questionnaire to the respondents. Data collected were analyzed using descriptive statistics, weighted mean obtained from Likert scale, and Tobit regression model. The results of the socioeconomic characteristics of farmers showed that majority of the farmers had formal education and only $15.19 \%$ had no formal education, $56.74 \%$ of the farmers had 11 years of farming experience. The farmers' risk perception showed that the most important risk factors perceived by cassava farmers in their farm were flooding/erosion, increased frequency and intensity of rainfall and incidence of pest and diseases. The factors that influenced the farmers' level of risk perception included age, level of education, access to extension agents and access to climate change information. Based on the findings of cassava farmers' level of risk perception, it was inferred that the farmers have reasonable perception of climate change risk. It was therefore recommended from the findings of this research that there is need for effective and functional extension services and provision of enabling environment and policies that will help boost the socio-economic welfare of farmers as this will significantly help in the management of climate change risk in the study area.
\end{abstract}




\section{Keywords}

Climate Change, Risk, Perception, Cassava Farmers

\section{Introduction}

Climate change is now a serious and long-term threat that has the potential to affect every part of the globe. The impacts of climate change are already being felt in many sectors, and the attendant harm. Pan African Climate Justice Alliance (PACJA, 2009) findings reviewed that recent evidence indicates that the world has already warmed by $0.8^{\circ} \mathrm{C}$ since the pre-industrial era.

Climate models suggest that Africa's climate will generally become more variable, with high levels of uncertainty regarding climate projections in the Africa Sahel zone. Temperatures in West Africa, and particularly the Sahel, have increased more sharply than the global trend, and the average predicted rise in temperature between $1980 / 99$ and $2080 / 2099$ is between $3^{\circ} \mathrm{C}$ and $4^{\circ} \mathrm{C}$, which is more than 1.5 times the average global trend (PACJA, 2009). The risks associated with increasing climate variability pose technological and economic challenges to societies which are dependent on agriculture for their livelihood. The consequences of observed and projected climate change have and will undermine indigenous ways of life that have persisted for thousands of years (Obama, 2014). There is a general consensus among scientists, economists, and policy makers that the entire globe is facing a real and serious long-term threat from climate change (Hansen et al., 2007). Projections suggest that, by the end of the 21 st century, climate change would have had substantial impact on agricultural production and, hence, on the scope for reducing poverty (Slater et al., 2007). Evidence has shown that changing climate is already affecting crop yields in many countries (Intergovernmental Panel on Climate Change, IPCC, 2007). This is particularly true in low-income countries like Nigeria where climate is the primary determinant of agricultural productivity and adaptive capacities are low (Apata et al., 2009). Many African countries including Nigeria, which have their economies largely dependent on weather-sensitive agricultural production systems, are particularly vulnerable to climate change. According to Apata et al., (2010), this vulnerability has been demonstrated by the devastating effects of recent flooding in different parts of the country and the various prolonged droughts that are currently being witnessed in some parts of Northern region.

Appropriate risk perception can be seen as a prerequisite for choosing an effective risk-coping strategy, because a farmer that is not aware of the risks faced is clearly unable to manage them effectively. This problem of risk perception was discussed, among others, by Pennings \& Leuthold (2000). Farmers' risk perception was studied by several other authors, and most of them concentrated on identifying the risk factors that were seen by farmers as the most important. The farmers quoted various risk factors as being important such as drought (Greiner 
et al., 2008), animal disease, pests, personal safety and health risk (Blank \& McDonald, 1995), yield risk and price risk for agricultural products (Palinkas \& Székely, 2008), institutional risk connected with farm support (Flaten et al., 2005), and weather and natural disasters (Palinkas \& Székely, 2008). Some authors dealing with the issue of risk perception (Borges \& Machado, 2012) focused on finding factors determining differences in the level of risk perception. They concluded that these differences are determined by the socio-economic features of the farmers and the characteristics of their farms. One has to be aware of the fact that farmers from various countries live within different climatic and institutional conditions, thus the differences of risk perception can be a result of either different probabilities of certain risk factors, or different farmers' mentality and awareness, or a mixture of both.

In Sub-Saharan Africa, farmers are key stakeholders in the climate change debate. However, knowledge of rural farmers of the South-East region of Nigeria about climate change has been noted to be abysmally low. Their understanding and perceptions of what climate change is and the extent to which it has changed and its effect on agriculture are still vague, even though it is not in doubt that the climate system has deflected from its original status. According to Nwaiwu (2014), it is not known to what extent farmers in Nigeria perceive changes in the climate variables and the effects they have on crop production. Furthermore, the physical evidences of climate change as contained in available literature are still imprecise and not consistent with the observed variations in the climate of Nigeria and South-East in particular.

There are diverse opinions in literature to the effect that rural farmers' knowledge of climate change effect is insufficient for reliable adaptation. Some scientists also perceive that rural farmers' knowledge is insufficient for rigorous evaluation of planned adaptation. The IPCC report (IPCC, 2014) reveals, however, that local awareness and vulnerabilities are increasingly being incorporated in interdisciplinary, multi-stakeholder assessments. The report of the IPCC and previous studies in Africa have shown the need for assessments of the potential impacts of climate variability/change and for the integration of rural farmers awareness of these impacts alongside other weather stresses (Van Griensven et al., 2016).

\section{Methodology}

The study was done in Anambra State, located in South-East Nigeria. The State is located between latitudes $6^{\circ} 45^{\prime}$ and $5^{\circ} 44^{\prime}$ of the Equator and longitudes $6^{\circ} 36^{\prime}$ and $7^{\prime} 20^{\prime} E$ of the Greenwich Meridian. It shares boundaries with Delta, Imo, Kogi, and Enugu States. The total land area is 4844 square $\mathrm{km}$ with a population of 4,182,032 persons (NPC, 2006). The State has four agricultural zones, three senatorial districts and twenty one Local Government Areas (LGAs).

Both primary data and secondary information were sourced. A multistage sampling technique was adopted. At the first stage, two LGAs were purposively 
selected from each of the four Agricultural Zones based on predominance of agricultural activities, making a total of 8 LGAs. Secondly, from each selected LGAs, five communities were randomly selected from the list of communities in the different LGAs to give a total of 40 communities. In each of the selected communities, two villages were selected making a total of 80 villages. Two cassava farmers were selected randomly from each village to give the sample size of 160. Primary data were collected using questionnaire/interview schedule. The data collected includes socioeconomic characteristics of the farmers and farmers' perception of climate change. All collected data were cleaned through careful inspection of questionnaire and a total of 141 were actually used.

\section{Data Analysis}

Data collected were analyzed using descriptive statistics, weighted mean obtained from a 5-point Likert scale and Tobit regression model. The Tobit regression model was used to identify and examine factors influencing cassava farmers' level of Risk Perception. The dependent variable $Y$ is the risk perception index of the farmers in the area as measured from the degree each farmer perceived each climate change risk factors that challenges his production level in relation to the maximum obtainable value as expressed in Equation (1). Each farmer is allowed to state his perceived degree of each factor as it is applicable to his production activities. The summative value for all perceived climate risk factors of an $I^{\text {th }}$ farmer represents the actual perception index of the farmer and it is expressed as the percentage of maximum obtainable perception index. The percentage perception index $(Y)$ in Equation (1) is obtained as:

$$
Y=\left\{\frac{\text { Actial Perception index of an ith farmer }}{\text { Maximum obtainbale climate risk perception }}\right\} 100
$$

The independent variable include such variables such access to extension agents, level of experience, age, gender, educational level, access to climate information and farmers group membership.

In its simplest form, the Tobit regression model is presented as:

$$
\mu_{i}^{*}=\beta X_{i}+\varepsilon_{i}
$$

Algebraically expressed for the $i^{\text {th }}$ farmer,

$$
\begin{gathered}
\mu_{i}=B_{0}+B_{1} X_{1 i}+B_{2} X_{2 i}+\cdots+B_{N} X_{N} i \cdots ; i=1,2, \cdots, N 3 \\
\mu_{i}=\mu_{i}^{*} \text { if } 0<\mu^{*}<1(i=1, \cdots, n) \\
\mu_{i}=0 \text { if } \mu_{i}^{*} \leq T^{\prime} \\
\mu_{i}=1 \text { if } \mu_{i}^{*}>T
\end{gathered}
$$

where: $\mu_{i}=$ perception in percentage

$T=$ the critical (cut off) value which translates into $\mu_{i}^{*}>T$ as a farmer perception to climatic effect is high, and $\mu_{i}^{*}<T$ as a farmer stated otherwise 
$n=$ the number of observations.

$\varepsilon_{i}=$ assumed to be independently normally distributed

Where: $X_{1}=$ Age (years), $X_{2}=$ Gender (Dummy: $1=$ male, $0=$ female), $X_{3}=$ Educational Level (years), $X_{4}=$ Farming Experience (years), $X_{5}=$ Access to extension agents, $X_{6}=$ Access to climate information and $X_{7}=$ Farmers group membership ( 1 if yes, 0 if no).

\section{Results and Discussion}

\section{Socioeconomic Characteristics of Cassava Farmers}

Table 1 shows that majority (54.56\% i.e. $24.82 \%$ and $29.78 \%$ ) of the respondents were between 35 - 54 years of age. The mean age was 39 years. The predominance of middle age individuals in cassava farming in the area is not unusual

Table 1. Frequency and percentage distribution of respondents according to socioeconomic characteristics.

\begin{tabular}{|c|c|c|c|}
\hline Characteristics & Categories & Frequency & Percentage (\%) \\
\hline \multirow[t]{6}{*}{ Age (years) } & $15-24$ & 7 & 4.97 \\
\hline & $25-34$ & 32 & 22.70 \\
\hline & $35-44$ & 35 & 24.82 \\
\hline & $45-54$ & 42 & 29.78 \\
\hline & $55-64$ & 25 & 17.73 \\
\hline & Mean 39 yrs & & \\
\hline \multirow[t]{2}{*}{ Gender } & Male & 88 & 62.41 \\
\hline & Female & 53 & 37.59 \\
\hline \multirow[t]{6}{*}{ Farming experience (years) } & $1-5$ & 20 & 14.18 \\
\hline & $6-10$ & 64 & 45.39 \\
\hline & $11-15$ & 16 & 11.35 \\
\hline & $16-20$ & 26 & 18.44 \\
\hline & $21-25$ & 15 & 10.64 \\
\hline & Mean 11.3 years & & \\
\hline \multirow[t]{5}{*}{ Educational Level } & 0 (No formal Education) & 21.42 & 15.19 \\
\hline & $1-6$ & 21 & 14.89 \\
\hline & $7-12$ & 53 & 37.55 \\
\hline & $13-18$ & 65 & 46.10 \\
\hline & Mean 11 yrs & & \\
\hline \multirow[t]{4}{*}{ Household Size } & $1-5$ & 61 & 43.26 \\
\hline & $6-10$ & 70 & 49.65 \\
\hline & $11-15$ & 10 & 7.09 \\
\hline & Mean 6 persons & & \\
\hline
\end{tabular}

Source: Field Survey Data, 2019. 
given the unavailability of other livelihood activities and consequently the high rate of unemployment in the society. Farmers within this age bracket are seen to be energetic and active and can favourably source for and understand information on climate variation owing to the fact that majority of them are educated.

The result in the table also shows that the sampled cassava farmers in the study area were of varying educational qualifications. The mean level of education was 11 years. Only $15.19 \%$ had no formal education. This implies that farmers in the area are largely literate and should favourably understand variation in climate and its effect on crop production, while also responding to the call for human capacity building.

The distribution of cassava farmers according to sex showed that $62.41 \%$ of the respondents were males and $37.59 \%$ were females with a margin of $24.82 \%$. This implies that men are more involved in cassava production in the area. Differences in awareness or perception may not be highly expected as climate change and variability impacts both men and women, although men and women may experience differences in the severity of impact due to differences in vulnerabilities. But it greater involvement of men can be said to improve perception in the area since women are said to have limited access to farm resources such as agricultural extension and financial services that can aid perception (Beuchelt \& Badstue, 2013).

The result also shows that majority (45.39\%) of the cassava crop farmers had between 6 to 10 years of farming experience, 10.64\% of them had above 21 years of experience while the mean farming experience was 11.3 years. This shows that the farmers have devoted a reasonable number of their years to farming business given that their mean age is 39 years. This implies positive effect on production efficiency due to the knowledge and skills acquired over the years of involvement.

Most of the respondents (49.65\%) had household size of between 6 and 10 persons with a mean household size of 6 persons. Farmers with larger household size depended more on family labour than hired labour and this enables them channel more funds and available resources to other household needs. This is in line with the findings of Henri-Ukoha et al., (2015) who asserted that households with greater number of members especially those not dominated by children are more advantaged since traditional farming require much manual labour and there will be more hands to assist in other farming activities.

\section{Cassava Farmers Climate Change Risk Perception}

Table 2 shows the perception of cassava famers on different climate change risk factors. This brings to light two major perspectives; knowledge of the effect of climate change and the extent of the effect of each factor on cassava crop production. The weighed mean from Likert scale was employed for the analysis. The result shows that in the area, flooding/erosion with a mean value of 3.36 showing very excessive was perceived by farmers to be the most important risk factor on their farms. This is in line with the findings of Eze et al., (2016), who asserted that flooding had negative and significant effect on crop production in 
Table 2. Distribution of farmers according to their climate change risk perception.

\begin{tabular}{|c|c|c|c|c|c|c|c|}
\hline \multirow{2}{*}{ Climate Risk Variables } & \multicolumn{5}{|c|}{ Degree of Perception } & \multirow{2}{*}{ Mean } & \multirow{2}{*}{ Remarks } \\
\hline & Very Excessive & Excessive & Undefined & Less Excessive Not & Excessive & & \\
\hline Drought and crop wilting & 4 & 12 & 110 & 9 & 6 & 1.99 & Undecided \\
\hline High temperature & 6 & 19 & 37 & 68 & 11 & 1.58 & Less Excessive \\
\hline Low temperature & 2 & 35 & 29 & 49 & 26 & 1.56 & Less Excessive \\
\hline Increased Rainfall Frequency & 40 & 68 & 14 & 8 & 5 & 2.84 & Excessive \\
\hline Increase in Rainfall Volume & 43 & 59 & 26 & 10 & 3 & 2.91 & Excessive \\
\hline $\begin{array}{l}\text { Late rainfall records or } \\
\text { Delay in onset of rainfall }\end{array}$ & 1 & 15 & 100 & 12 & 5 & 1.85 & Undecided \\
\hline Incidence of crop pest and diseases & 21 & 62 & 37 & 10 & 11 & 2.51 & Excessive \\
\hline $\begin{array}{l}\text { Extended solar hour or Sunshine hours } \\
\text { (Change in sunshine intensity) }\end{array}$ & 3 & 12 & 104 & 9 & 13 & 1.80 & Undecided \\
\hline $\begin{array}{l}\text { Hailstorms/Windstorm or Changes in } \\
\text { wind pattern/speed }\end{array}$ & - & 13 & 98 & 11 & 19 & 1.74 & Less Excessive \\
\hline Flooding/Erosion & 81 & 46 & 3 & 6 & 5 & 3.36 & Very Excessive \\
\hline
\end{tabular}

Source: Field Survey Data, 2019.

the South eastern part of Nigeria as soil nutrient are eroded in the case of frequent flood incidences. Increased rainfall frequency, increased rainfall volume and incidence of crop pest and diseases had mean values of 2.84, 2.91 and 2.51 respectively showing that their effects were excessive; Drought and crop wilting, late rainfall records and extended sunshine/solar hours had mean values of 1.99, 1.85 and 1.80 respectively showing that their effects were undecided while high temperature, low temperature and Hailstorms/Windstorm or Changes in wind pattern/speed respectively had mean values of $1.58,1.56$ and 1.74 showing that they were less excessive. The respondents perceived the most important risk factor on their farms to be flooding/erosion (mean value 3.36) while the least was low temperature (mean value 1.56). However, the reason for this might be that the farmers have problems with distinguishing one climate change risk factor from the other or they find it difficult to assess which of these factors caused certain damage. But from the result obtained, it can be said that the respondents had reasonable perception of the effects of the various risk factors on cassava crop production.

\section{Factors Influencing Cassava Farmers Level of Risk Perception}

Table 3 shows the result of the estimation of factors which affects cassava farmers' perception level in the study area.

The result in Table 3 shows that the coefficient of age was significant $(p<$ 0.01 ) and negatively signed. This implies that there is a negative relationship between age of the farmer and his risk perception index and the probability that the farmer would have a high risk perception index decreased by about $6.0 \%$ for every unit increase in the age of the farmer. This implies that older farmers had 
Table 3. Factors influencing cassava farmers' level of risk perception.

\begin{tabular}{|c|c|c|c|c|c|c|}
\hline \multirow{2}{*}{ Explanatory variables } & \multicolumn{3}{|c|}{ Co-efficients } & \multicolumn{3}{|c|}{ Marginal Effects } \\
\hline & Co-efficients & z-values & $P>|\mathrm{z}|$ & co-efficients & z-values & $P>|\mathrm{z}|$ \\
\hline $\begin{array}{l}\text { Constant } \\
\text { (Std. Error) }\end{array}$ & $\begin{array}{c}0.8105619 \\
(0.823)\end{array}$ & 0.98 & 0.327 & - & - & - \\
\hline $\begin{array}{c}\text { Age } \\
\text { (Std. Error) }\end{array}$ & $\begin{array}{c}-0.052601 \\
(0.015)\end{array}$ & -3.45 & $0.000^{* * *}$ & $\begin{array}{c}-0.0606016 \\
(0.0152)\end{array}$ & -3.99 & $0.000^{* * *}$ \\
\hline $\begin{array}{c}\text { Sex } \\
\text { (Std. Error) }\end{array}$ & $\begin{array}{c}-0.3751384 \\
(0.421)\end{array}$ & -0.89 & 0.374 & $\begin{array}{c}-0.3751384 \\
(0.421)\end{array}$ & -0.89 & 0.372 \\
\hline $\begin{array}{l}\text { Formal education } \\
\text { (Std. Error) }\end{array}$ & $\begin{array}{c}0.098964 \\
(0.049)\end{array}$ & 2.03 & $0.044^{* *}$ & $\begin{array}{c}0.098964 \\
(0.048)\end{array}$ & 2.03 & $0.042^{* *}$ \\
\hline $\begin{array}{c}\text { Farming experience } \\
\text { (Std. Error) }\end{array}$ & $\begin{array}{c}0.0304702 \\
(0.029)\end{array}$ & 1.06 & 0.290 & $\begin{array}{c}0.0304702 \\
(0.029)\end{array}$ & 1.06 & 0.288 \\
\hline $\begin{array}{l}\text { Extension contact } \\
\text { (Std. Error) }\end{array}$ & $\begin{array}{c}0.6937906 \\
(0.412)\end{array}$ & 1.69 & $0.094^{*}$ & $\begin{array}{c}0.6937906 \\
(0.412)\end{array}$ & 1.69 & $0.092^{*}$ \\
\hline $\begin{array}{l}\text { Access to source of } \\
\text { information } \\
\text { (Std. Error) }\end{array}$ & $\begin{array}{c}1.3729591 \\
(0.490)\end{array}$ & 2.80 & $0.004^{* *}$ & $\begin{array}{c}1.3729591 \\
(0.490)\end{array}$ & 2.80 & $0.004^{* *}$ \\
\hline $\begin{array}{l}\text { Social capital } \\
\text { (Std. Error) }\end{array}$ & $\begin{array}{c}0.7383811 \\
(0.414)\end{array}$ & 1.78 & $0.077^{*}$ & $\begin{array}{l}0.7383811 \\
(0.414)\end{array}$ & 1.78 & $0.074^{*}$ \\
\hline \multicolumn{3}{|c|}{ Pseudo $\mathrm{R}^{2}$} & \multicolumn{4}{|c|}{0.5972} \\
\hline \multicolumn{3}{|c|}{ Log likelihood } & \multicolumn{4}{|c|}{-319.103} \\
\hline \multicolumn{3}{|c|}{$\mathrm{F}_{(7,137)}$} & \multicolumn{4}{|c|}{2.23} \\
\hline \multicolumn{3}{|c|}{ Number of observation } & \multicolumn{4}{|c|}{141} \\
\hline \multicolumn{3}{|c|}{ Left censored observation } & \multicolumn{4}{|c|}{0} \\
\hline \multicolumn{3}{|c|}{ Uncensored observation } & \multicolumn{4}{|c|}{140} \\
\hline \multicolumn{3}{|c|}{ Right censored observation } & \multicolumn{4}{|c|}{1} \\
\hline
\end{tabular}

Source: Field Survey Data, 2018 . Notes: ${ }^{* *},{ }^{* *},{ }^{*}=$ significant at $1 \%, 5 \%$, and $10 \%$ probability level, respectively. Figures in parentheses $=P$-values.

lower risk perception indices and may thus be more vulnerable and susceptible to the vagaries of the climate especially in their farming activities.

The coefficient of years of formal education was significant $(p<0.05)$ and positively signed. This implies that the more years of formal education the farmer has, the higher the probability of his risk perception index. There is about $9.8 \%$ percent increase in risk perception for every unit increase in years of formal education. This result illustrates the role formal education plays in raising the individual's awareness of the impact of climate change and the risks it poses to his cassava crop production and means of livelihood. This is in line with the findings of Francis \& Tsunemi (2017) who asserted that two demographic variables (i.e., age and education) are significant predictors of climate change risk perception.

The coefficient of access to extension agent was significant $(p<0.10)$ and positively signed. This implies that the probability there will be an increase in farmer's risks perception index increases by about $69 \%$ for every increase in access to extension agent. This is another illustration of the key role extension agents play in getting information to the farmers most of whom do not have access to other conventional sources of information.

The coefficient of access to information was significant $(p<0.01)$ and posi- 
tively signed indicating that the probability of an increase in the farmer's risk perception index increase by 1.37 unit for every increase in access to information. This result further underscores the importance of information dissemination especially as it relates to climate change and the risk it poses to the farmer's livelihood.

The coefficient of cooperation society (social capital) was significant $(p<0.10)$ and positively signed thus implying that the probability of an increase in the farmers' risk perception index increases by about $74 \%$ for every increase in cooperative membership. This result further strengthens the argument that cooperative membership is a veritable tool for both economic and social development of the farmer.

\section{Conclusion and Recommendation}

This study examined cassava farmers' climate change risk perception and the factors influencing it. The farmers in the study area identified factors such as educational level, access to extension agents, access to climate information and farmers' group membership as factors influencing the farmers' level of perception. The cassava farmers also perceived flooding, incidence of pests and diseases, increased volume of rainfall and increased frequency of rainfall as major sources of risk on their farms that resulted from climate change. This perception is the first step towards adopting effective and efficient technologies that will aid in proper climate change risk management.

Following from the findings of the study, the study therefore recommended that, there should be more education on the occurrence of climate change risk factors and the attendant risks to their crops via extension education. There is also need to strengthen the implementation of environmental protection policies in the study area.

\section{Conflicts of Interest}

The authors declare no conflicts of interest regarding the publication of this paper.

\section{References}

Apata, T. G., Ogunyinka, A. I., Sanusi, R. A., \& Ogunwande, S. (2010). Effects of Global Climate Change on Nigerian Agriculture: An Empirical Analysis. In 84th Annual Conference of the Agricultural Economics Society (p. 2).

Apata, T. G., Samuel, K. D., \& Adeola, A. O. (2009). Analysis of Climate Change Perception and Adaptation among Arable Food Crop Farmers in South Western Nigeria. In the International Association of Agricultural Economists'2009 Conference (p. 205).

Beuchelt, T. D., \& Badstue, L. (2013). Gender, Nutrition and Climate-Smart Food Production: Opportunities and Trade-Offs. Food Secure, 5, 709-721.

https://doi.org/10.1007/s12571-013-0290-8

Blank, S. C., \& McDonald, J. (1995). How California Agricultural Producers Manage Risk. California Agriculture, 49, 9-12. https://doi.org/10.3733/ca.v049n02p9 
Borges, J. A. R., \& Machado, J. A. D. (2012). Risks and Risk Management Mechanisms: An Analysis of the Perceptions of Producers of Agricultural Commodities. Interdisciplinary Journal of Research in Business, 2, 27-39.

Eze, C. C., Korie, O. C., Ben-Chendo, G. N., \& Nwaiwu, I. U. (2016). Socio-Economic Effects of Climate Change Variables on Cocoyam Production in Nigeria. Futo Journal Series, 2, 210-235.

Flaten, O., Lien, G., Koesling, M., Valle, P. S., \& Ebbesvik, M. (2005). Comparing Risk Perceptions and Risk Management in Organic and Conventional Dairy Farming: Empirical Results from Norway. Livestock Production Science, 95, 11-25. https://doi.org/10.1016/j.livprodsci.2004.10.014

Francis, N., \& Tsunemi, W. (2017). Determinants of Farmers' Climate Risk Perceptions in Agriculture: A Rural Ghana Perspective. Basel: MDPI.

Greiner, R., Patterson, L., \& Miller, O. (2008). Motivation, Risk Perceptions and Adoption of Conservation Practices by Farmers. Agricultural Systems, 99, 86-104. https://doi.org/10.1016/j.agsy.2008.10.003

Hansen, J. W., Baethgen, W., Osgood, D., Ceccato, P., \& Ngugi, R. K. (2007). Innovations in Climate Risk Management: Protecting and Building Rural Livelihoods in a Variable and Changing Climate. SAT eJournal, 4, 1-38.

Henri-Ukoha, A., Anaeto, F. C., Chikezie, C., Ibeagwa, O. B., Ukoha, I. I., \& Oshaji, I. O. (2015). Analysis of Cassava Value Chain in Ideato South Local Government Area, Imo State, South-East Nigeria. International Journal of Life Sciences, 4, 200-211.

Intergovernmental Panel on Climate Change (IPCC) (2014). Climate Change 2014 Impacts, Adaptation and Vulnerability: Regional Aspects. Cambridge: Cambridge University Press. https://doi.org/10.1017/CBO9781107415416

IPCC (2007). Summary for Policymakers. In S. D. Solomon, M. Qin, Z. Manning, M. Chen, K. Marquis, M. Averyt, \& M. H. Tignor, (Eds.), Climate Change 2007: The Physical Science Basis. Contribution of Working Group I to the Fourth Assessment Report of the Intergovernmental Panel on Climate Change (pp. 853-858). Cambridge: Cambridge University Press.

Nwaiwu, I. U. (2014). Effects of Climate Change on Labour Use Efficiency and Sustainable Food Crop Production Systems in Southeast Nigeria. An Unpublished Thesis, Owerri: Department of Agricultural Economics, Federal University of Technology Owerri.

Obama, B. (2014). Obama's Climate Change Reports Lays out Dire Scenario, Highlights Effects on Natives. President Barack Obama's Third U.S. National Climate Assessment Release on May 6, 2014. Indian Country Today Media Network May, 82014.

PACJA (PanAfrican Climate Justice Alliance) (2009). The Economic Cost of Climate Change in Africa.

Palinkas, P., \& Székely, C. (2008). Farmers' Perceptions on Risk and Crisis Risk Management. In M. P. M. Meuwissen, M. A. P. M. Asseldonk, \& R. B. M. Huirne (Eds.), Income Stabilization in European Agriculture. Design and Economic Impact of Risk Management Tools (pp. 97-122). Wageningen: Wageningen Academic Publishers.

Pennings, J., \& Leuthold, R. (2000). The Role of Farmers' Behavioral Attitudes and Heterogeneity in Futures Contracts Usage. American Journal of Agricultural Economics, 82, 908-919. https://doi.org/10.1111/0002-9092.00090

Slater, R., Peskett, L., Ludi, E., \& Brown, D. (2007). Climate Change, Agricultural Policy and Poverty Reduction-How Much Do We Know? Natural Resource Perspectives No. 109. 
Van Griensven, A., Vetter, T., Piontek, F., Gosling, S. N., Kamali, B., Reinhardt, J., Dinkneh, A., Yang, H., \& Alemayehu, T. (2016). Inter-Sectoral Comparison of Model Uncertainty of Climate Change Impacts in Africa. EGU General Assembly Conference Abstracts 14211 . 